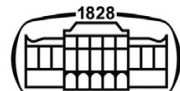

AKADÉMIAI KIADÓ

UNIVERSITY of DEBRECEN

\section{International Review of Applied Sciences and Engineering}

13 (2022) 1, 88-97

DOI:

10.1556/1848.2021.00312

(c) 2021 The Author(s)

\section{ORIGINAL RESEARCH} PAPER

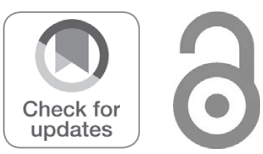

\title{
Motivations of an active lifestyle to the benefit of a healthy society: A study of consumer motivations and their choices of fitness facilities
}

\author{
Éva Judit Bartha* and Éva Bácsné Bába
}

Faculty of Economics and Business, University of Debrecen, Debrecen, Hungary

Received: May 5, 2021 • Accepted: July 19, 2021

Published online: September 1, 2021

\begin{abstract}
Our study aims to discover what reasons justify the physical activity of fitness consumers, and how the motivation of this physically active group can be maintained, which then may contribute to maintain a healthy society in the long run. Of the primary research procedures we chose to use the questionnaire survey method. We used cluster analysis for which we used principal components that were created with factor analysis to determine what groups can be established based on responses to the questions related to motivation and the factors that influence their choices of facilities. Based on the rank order of motivations influencing attendance of fitness sessions, fitness consumers were stratified into four different clusters. Then, segmentation of the consumers was done based on the factors influencing their choices of facilities. Our results lead to the conclusion that the motivation of consumer groups identified in our research can be sustained in the long run, the less active groups can be better involved and attracted to sports offered by fitness centres, on condition the fitness studios reliably serve these needs and provide the expected variety of services and hygienic conditions.
\end{abstract}

\section{KEYWORDS}

fitness services, fitness clubs, fitness consumers, motivation

\section{INTRODUCTION}

The sports facilities of the fitness sector and fitness clubs are playing an increasingly important role as one of the possible venues for everyday recreational sports [1]. Managing a fitness facility can be a complex and responsible task. In order to maintain the competitiveness of such a facility in the face of increasing competition in the sector and the growing number of replacement services, managers of fitness clubs need to be able to map consumer expectations of sports facilities from different groups of fitness consumers. Regardless of the size and services of sports facilities, one of the most important managerial competencies is how a sports facility manager communicates with consumers visiting a fitness club [2, 3]. Proper communication is also essential to assess demand trends and it can help a fitness club manager to encourage consumers to make greater use of the services provided by the facility.

In highly competitive sectors like the fitness business, an indispensable ingredient of survival and success is the quality excellence of services offered, consequently more and more managers focus on meeting the high expectations of consumers [4]. In parallel with the rising of the number of fitness services, the knowledge of the fitness consumers about these new trends has also increased, and made their expectations more complex [1].

One feature of fitness services is that the consumer himself/herself takes part in producing

*Corresponding author. E-mail: bartha.eva.judit@econ.unideb. hu and using the service product, therefore it is of essential importance how the quality of the service is perceived $[5,6]$.

Afthinos et al. (2005) studied the expectations of consumers of Greek fitness clubs towards sports facilities in public and private fitness clubs in Athens based on the differences in sex, age and motivation [7]. According to their hypothesis athletes have similar expectations 
of the quality of fitness clubs despite the differences in motivation (health, fitness or weight control). Their results showed that the clientele of the fitness centres rank down-toearth elements of the services the highest: physical environment, prices, variety and time points of the programs offered, and professionalism and attitude of the staff. This confirms the claims of Chelladurai-Chang (2000), who found interaction between consumers and the staff offering the service to be a key factor [8].

Korean consumers of fitness service providers are in the focus of Kim-Kim's (1995) Quality Excellence of Sport Centres (QUESC) model. According to this clients' choices are primarily influenced by the physical environment, the atmosphere of the club, attitude and attention of the staff, various privileges, reliability, availability of information, programs and their prices, the motivating, liberating atmosphere and comfort [9].

Chelladurai-Chang (2003) created the Scale of Quality in Fitness Services (SQFS) model, which defines the operation of the fitness services as a system made up of input, process and output. The model proposes nine dimensions that can describe the quality of services. The input factors include the atmosphere of services, dedication of the management to quality, and the services themselves. Factors of the process are defined as professional interactions with the staff, personal interactions with the staff and other clients, physical environment and the process of avoiding and correcting potential mistakes. Based on the model the output factor is defined as the quality as perceived by the clients using the sport services [10].

According to Szabó (2012) clients of the Hungarian fitness clubs are influenced by other factors as well when choosing a sport facility. Interviews with the representatives of the fitness sector have revealed that consumers of the fitness clubs in Hungary are significantly influenced by the distance of the club from either their home or their workplace. They judge the quality of the fitness services based on the politeness, friendliness and professionalism of the staff, the condition of the interior rooms, the style, cleanliness, equipment and additional services. It is an important factor in selecting a fitness club how appropriate the client-files are maintained, how user-friendly and interactive the homepage of the place is. They found the role of personal interactions and relationships weightier than the physical environment [11].

Several studies have investigated the factors that motivate recreational athletes to do sports. Aims and motivations spurring on athletes to engage in sports depend on several factors. Kilpatrick et al. (2010) differentiated exercises from other sports based on the primary motivations. According to him the main motivations for sport participation are competition, the feeling of belonging, enjoyment of sports and the challenge, while the motivating factors of exercise are more health and appearance related. He found gender based differences in the main motivations too. While for women body shaping and aesthetic appearance are key factors, for men these are of lesser importance, they find performance, challenge, strength, stamina, competition and appreciation more important. These differences can be seen irrespective of the type of sport they do. Besides, a lot of men also considered fitness exercises to be instrumental in reaching their ego-inspired goals [12].

Molanorouzi et al. (2015) stress the significance of intrinsic and extrinsic motivations regarding physical activities. They consider commitment to sports, triggered by joy and satisfaction intrinsic motivation. Effects from outside, expectations and reward are considered to be extrinsic motivation. Their research encompassed the differences of genders as well, claiming that men are more motivated by contests, self-assurance, the feeling of power, whereas women are driven by looks and good physical condition [13]. Successful physical activity maintenance is usually supported by both intrinsic (interest, fun) and extrinsic motives (appearance, social motives) [14].

Based on the survey on a sample size of three thousand people, Gál (2014) concluded that the strongest motives to do recreational sport in Hungary are preservation of health, increase of physical capacity and leisure. She also stresses gender differences; men are driven mostly by entertainment and spending time together with friends, while women are more interested in weight control, sustaining the shape of the body and fighting age [15].

Biddle-Mutrie (2001) claim that motivation changes with age. In childhood the primary drive to engage in sport activities is enjoyment, fitness, developing skills, belonging to a group, success and challenge. As a young adult challenge is the primary aim besides fitness and improvement of skills, while older adults are spurned on by health considerations, relaxation and enjoyment [16].

Gender differences were also central in the research study conducted by Trujillo et al. [13], who came to the conclusion that for old people maintenance and improvement of health are gaining more and more importance. Molanorouzi et al. (2015) stress gender differences as well and state that older consumers' motivation is more extrinsic when compared to those of the young [13]. Frederick-Ryan (1993) studied differences in motivation for individual sports (like tennis and sailing) and fitness trainings or exercises. Their results showed that individual sports are chosen by participants driven by interest/enjoyment and a feeling of being competent, while consumers choosing exercises were mostly driven by body related motivations [17].

As a result of the survey carried out by Neulinger (2007) in Hungary, the majority of respondents (82\%) listed preserving health and fitness as the main reasons for doing sports. The next most frequently mentioned motives were recreation and relaxation (73\%), love of exercising (72\%), improvement of physical capacities (69\%) and relieving stress $(62 \%)$. The results of her survey also confirmed that women do sport to maintain and improve their body shape, while for men company and relaxation are more important [18].

In view of the results of the Hungarian Youth Study (A Magyar Ifjúság Kutatás) completed in 2016, 74-75\% of young people doing sport regularly were driven by the goal of achieving and preserving fitness and health. Sixty-two 
percent of the respondents mentioned the joy of sport as the main motivating factor, $61 \%$ mentioned well-being and 58\% good physical appearance. One fifth of the young people regularly exercising aim to lose weight, and 39\% consider sports as a community program. Twelve percent do sport because their parents insist on it [19].

A survey also carried out in Hungary stresses motivating factors that are related to the social life of athletes. The most influential of these include physical fitness; recreation, fun; love of sports; attractive body shape, good company; relieving stress and tension; company of athletic friends; competitions, winning; family and work place expectations [20].

Being aware of the factors that we studied in our research enables us to increase the satisfaction level of consumers and as a consequence to preserve their physical activity and also to attract bigger groups, since these factors help to shape and assure conditions that can meet the needs of various groups (gender, age). Identifying these factors (main motivating factors for sport and main aspects of facility choice) will also help the managers of sports facilities to operate fitness clubs more successfully and profitably.

Our study aimed to discover how the motivation of fitness consumers could be maintained, which then might contribute to maintain a healthy society in the long run. The main contribution of our study was the segmentation of fitness consumers in different groups established based on responses to the questions related to motivation and the factors that influence their choices of facilities.

\section{MATERIAL AND METHOD}

Of the primary research procedures we chose to use the questionnaire survey method. The survey was accessible both online and in a paper format. When composing the questionnaire we strived to synchronize the factors we studied with the objectives of our research. The subject of our study determined the target groups of the survey, and thus the respondents were recreational athletes visiting fitness studios and attending instructor lead trainings. People filling in the survey were informed that responding was voluntary and anonymous, and they were told about the objective of the research.

The questionnaire surveys the following dimensions: general data, demographic data, habits of visiting the training sessions, considerations when choosing a fitness studio, and motives and goals of participating in trainings.

The questionnaire consisted of open and closed questions and Likert scales were used to assess the measure of agreement with certain statements [21]. The importance of considerations when selecting a fitness studio was examined with a 4 point Likert scale to avoid clustering of responses around the mean [22].

The online survey link was used for snowball sampling; it was sent to subjects, and then they provided referrals to their acquaintances. The questionnaire was filled in by 753 recreational athletes who visit fitness studios regularly.
We used cluster analysis for which we used principal components that were created with factor analysis to determine what groups can be established based on responses to the questions related to motivation and the factors that influence their choices of facilities. By segmenting the respondents we created relatively homogenous groups the members of which are similar to each other, while based on certain features different from others [23]. Finally we analysed the differences between the clusters with variance analysis, the Mann-Whitney test and the Kruskal-Wallis test.

Altogether 753 fitness studio goers filled in the questionnaires, 500 females and 253 males (66\% and $34 \%$ respectively). The next step in analysing socio-demographic data was to analyse the age range of the groups. $86 \%$ of the customers (647 people) were between 18 and 65, with the majority (252 people) being between 18 and 25 . The fewest (only 8) people were over 65 , while the under 18 were represented by 98 people. Finally, we analysed the sample from the point of view of education, labour market position and financial situation. The results showed that the majority of customers had high levels of education. Fourty-three percent of respondents were college or university graduates (320 people), followed by customers with at least secondary school final examination (225 people). The vast majority of the respondents (94\%) consider their financial situation to be average or better than average. Altogether 359 people considered their financial situation average and 280 a little better than average and another 70 much better than average. Only 44 respondents, an insignificant number of the population examined found their financial situation to be below average.

\section{RESULTS}

\subsection{Primary motives of fitness consumers}

The results of our study, where the respondents were asked to assess various motivational factors on a Likert scale, showed that recreational athletes regularly visiting fitness studios are mostly motivated by the desire to preserve their health (4.44), increase their physical fitness (4.36), and have a better appearance, a more aesthetic body (4.29). These are then followed by the wish for mental relaxation (4.16), for stress relief (4.07) and mental recharging (4.07), the wish to improve strength (3.93), to find challenges (3.87), improve joint suppleness (3.80), shape the body by losing weight (3.67), shape the body by building muscles (3.51), enhance speed (3.44), fun and spending time (3.43), company (3.30) and appreciation (3.04). The fewest points were given to factors like treating physical complaints (2.95), competing with others (1.99), and expectations of the workplace (1.36), friends (1.35) and relatives (1.34) [24] (Table 1).

After analysing the order of importance of motivating factors, we examined whether consumer groups can be created based on the main motivations, and which members are similar in many aspects, but can be well distinguished from other groups. The Cronbach's alpha value obtained in the reliability test of the questions was 0.812 . The Kaiser- 
Table 1. Motivations of fitness consumers (mean values)

\begin{tabular}{|c|c|c|c|}
\hline Mental recreation & 4.16 & $\begin{array}{l}\text { Obligation: expected by } \\
\text { friends, acquaintances }\end{array}$ & 1.35 \\
\hline Stress relief & 4.07 & $\begin{array}{l}\text { Obligation: expected by } \\
\text { the workplace, colleagues }\end{array}$ & 1.36 \\
\hline Spiritual replenishment & 4.07 & $\begin{array}{l}\text { For recognition, to show } \\
\text { off my abilities }\end{array}$ & 3.04 \\
\hline Health protection & 4.44 & Competition with others & 1.99 \\
\hline $\begin{array}{l}\text { Treatment of physical } \\
\text { complaints }\end{array}$ & 2.95 & $\begin{array}{c}\text { Challenge, overcoming } \\
\text { myself }\end{array}$ & 3.87 \\
\hline $\begin{array}{l}\text { Improvement of } \\
\text { flexibility }\end{array}$ & 3.8 & Company & 3.3 \\
\hline $\begin{array}{l}\text { Improvement of } \\
\text { quickness }\end{array}$ & 3.44 & Entertainment, pastime & 3.43 \\
\hline $\begin{array}{l}\text { Improvement of stamina, } \\
\text { physical endurance }\end{array}$ & 4.36 & $\begin{array}{l}\text { Shape improvement by } \\
\text { muscle building }\end{array}$ & 3.51 \\
\hline Improvement of strength & 3.93 & $\begin{array}{c}\text { Better physical } \\
\text { appearance, more } \\
\text { aesthetic outlook }\end{array}$ & 4.29 \\
\hline $\begin{array}{l}\text { Obligation: expected by } \\
\text { parents, close relatives }\end{array}$ & 1.34 & & \\
\hline
\end{tabular}

Source: own edition.

Meyer-Olkin and Bartlett test showed a KMO $=0.82$; sp.: $171 ; P<0.01$. Principal component analysis was thus applicable, and six categories related to motivational factors were developed during its application (Table 2).

In our study the cluster analysis method was chosen in order to segment fitness consumers based on motivation. Our results show that based on the motivations respondents can be clustered into 4 well distinguishable groups and the variance analysis found the differences between them to be significant $(P<0.001)$. We examined what features characterise these clusters with regard to their make-up, to the participant's gender, age and financial situation, and whether there is any difference between the groups regarding the frequency of their participation in the fitness sessions (Table 3). Those who consider sociocultural factors and appreciation as their key driving motivation are classified into the "Sociable, active" cluster. The members of the "Athletic, well-conditioned" cluster consider the improvement of their conditional skills and muscle growth as their main goal. The "Healthy, fit" group consists of people who are health-conscious, and attend trainings mainly to improve their health and get attractive appearance. And finally, those who attend gym in order to fulfill some kind of obligation, meet expectations or working for external appreciation were classified into the "Externally controlled" cluster.

Results of the ANOVA analysis show that there are significant differences between the four clusters with respect to gender, age and frequency of participation in fitness sessions $(P<0.001, P<0.005$, and $P<0.01$ respectively).

\subsection{Cluster 1: Sociable, active}

Altogether 226 people are in this cluster. Their most important motivations for training are socio-cultural factors and motivations related to appreciation while the least
Table 2. Categories of motivational factors

\begin{tabular}{|c|c|c|}
\hline Factor & Statement & $\begin{array}{l}\text { Factor } \\
\text { loading }\end{array}$ \\
\hline \multirow[t]{5}{*}{ Health } & Mental recreation & 0.79 \\
\hline & Stress relief & 0.72 \\
\hline & Spiritual replenishment & 0.7 \\
\hline & Health protection & 0.66 \\
\hline & $\begin{array}{l}\text { Treatment of physical } \\
\text { complaints }\end{array}$ & 0.51 \\
\hline \multirow{4}{*}{$\begin{array}{l}\text { Conditional } \\
\text { abilities }\end{array}$} & Improvement of flexibility & 0.81 \\
\hline & Improvement of quickness & 0.8 \\
\hline & $\begin{array}{l}\text { Improvement of stamina, } \\
\text { physical endurance }\end{array}$ & 0.75 \\
\hline & Improvement of strength & 0.73 \\
\hline \multirow[t]{6}{*}{ Recognition } & $\begin{array}{l}\text { Obligation: expected by } \\
\text { parents, close relatives }\end{array}$ & 0.9 \\
\hline & $\begin{array}{l}\text { Obligation: expected by } \\
\text { friends, acquaintances }\end{array}$ & 0.89 \\
\hline & $\begin{array}{l}\text { Obligation: expected by the } \\
\text { workplace, colleagues }\end{array}$ & 0.87 \\
\hline & $\begin{array}{l}\text { For recognition, to show off } \\
\text { my abilities }\end{array}$ & 0.77 \\
\hline & Competition with others & 0.69 \\
\hline & Challenge, overcoming myself & 0.64 \\
\hline \multirow{2}{*}{$\begin{array}{l}\text { Sociocultural } \\
\text { motivations }\end{array}$} & Company & 0.82 \\
\hline & Entertainment, pastime & 0.78 \\
\hline \multirow[t]{2}{*}{ Better look } & $\begin{array}{l}\text { Shape improvement by muscle } \\
\text { building, weight increase }\end{array}$ & 0.81 \\
\hline & $\begin{array}{l}\text { Better physical appearance, } \\
\text { more aesthetic outlook }\end{array}$ & 0.74 \\
\hline
\end{tabular}

Principal component analysis. Varimax with Kaiser Normalization. A. Rotation converged in 9 iterations. $\mathrm{KMO}=0.822$. Bartlett (Approx. Chi-Square) 5,721.811; $P<0.001$; communalities: $0.502-$ 0.838 . Explained variance: $69,141 . N=748$.

Source: own edition.

motivating factors for them are looks. The rate of males $(33 \%)$ and females $(67 \%)$ in this population is similar to the base population, but their age is a little higher than that of the base population; they rank themselves into the better off category and go to fitness sessions more frequently, which makes this cluster the most active cluster regarding frequency of trainings. As friends and acquaintances are more important factors of trainings for the members of the group, and because they are considered the most active category, their cluster is named "Sociable, active".

We can presume that in the case of this group motivation for physical exercises has become internalised - intrinsic motivation - the time points of their fitness sessions have been incorporated into their daily routine. Since they are the most active regarding frequency of fitness sessions we can claim that socio-cultural factors are a substantial drive.

\subsection{Cluster 2: Athletic, well-conditioned}

The second cluster contains 169 respondents. Members of the cluster go to fitness sessions mostly because of factors related to motor performance abilities and looks, whereas the least motivating factor for them is health. Compared to 
Table 3. Features of motivation based clusters of consumers

\begin{tabular}{lccccr}
\hline & Sociable, active & Athletic, well-conditioned & Healthy, fit & Externally controlled \\
Variable & $N=226$ & $N=169$ & $N=291$ & $N=62$ & Sig. \\
\hline Female & $67 \%$ & $53 \%$ & $77 \%$ & $50 \%$ & $P<0.001$ \\
Male & $33 \%$ & $47 \%$ & $23 \%$ & $50 \%$ & 0.002 \\
Age & Older & Younger & Older & Younger & 0.200 \\
Financial status & Better & Worse & Average & Worse & Rare \\
Frequency of training & Frequent & Rare & Average & & 0.008 \\
\hline
\end{tabular}

Source: own edition.

the basic population the ratio of males (47\%) and the young is the highest here; they consider their financial situation somewhat lower than average and they go less often to trainings. As their main goal is the development of physical abilities in order to be athletic and to build muscles the group is named: "Athletic, well-conditioned".

The group consists of young people and mostly men, who nevertheless do not go to trainings as often as the base population. This may be due to the fact that looks is not such a long term motivation as the intrinsic motivation.

\subsection{Cluster 3: Healthy, fit}

The third cluster comprises 291 people. They primarily visit fitness studios because of health and appearance related motivational factors, and they are least motivated by social factors. The highest rate of women (77\%) and the older age groups are represented here, who find their own financial status to be average and they go to sessions more often than the majority. This is a health-conscious and active cluster which is therefore named "Healthy, fit".

This is also an active group with mostly females of the older generation. This is the largest group of responders and probably they constitute the majority of fitness studio goers. Regarding the older age group the previous statements are true for them as well: exercising has become an intrinsic motivation and they find its health preserving function very important. This group also demonstrates the typical factors analysed before; for them looks are essential and for this purpose they are willing to pursue an active lifestyle and do trainings regularly.

\subsection{Cluster 4: Externally controlled}

Sixty-two respondents are included in this cluster. Going to trainings for them is mostly duty and they attend sessions to gain acknowledgement; they are not motivated by looks. Of all clusters this comprises the most men (50\%, while the average of the base sample is 34\%), and most are young, who consider their financial status worse than average; they go to trainings the least frequently. As they try to meet expectations coming from outside, this group was named "Externally controlled".

The external expectations that are typical of the group do not constitute motivation in the long run. Young people are included here, who most likely go to trainings to comply with expectations of others, or perhaps because they are under pressure to go and not because it is their own intrinsic motive.
As a result of the cluster analysis fitness consumers have been segmented into 4 well-defined groups.

\subsection{Factors influencing the choice of facility}

We used a 4-point Likert scale to assess the factors that Hungarian fitness consumers consider when choosing the fitness facility for their sessions. The following list contains the factors in the order of their importance: cleanliness of the fitness studio (3.53), its equipment (3.45), cleanliness of changing rooms, sinks and showers (3.41) quality of basic services (3.25), personality of the trainer (3.18), good atmosphere, good company (3.11), price (3.07), location of the facility in the settlement (3.02), variety of basic services (2.94), friends', acquaintances' choices (2.56), parking options (2.34). The recreational athletes asked mentioned the following factors as the least important: quality of additional services (2.18), variety of additional services (2.03), reimbursement by the workplace (1.81), acceptance of trainings for university sport credits (1.64) (two semesters of sports at the university have to be accomplished by undergraduates) [25] (Table 4).

In relation with gym choice, we examined whether the number of the variables applied can be reduced, or whether they can be merged into specific factors. By using the principal component analysis, we created six independent components that reflect the gym choices of fitness consumers (Table 5).

Table 4. Aspects of the selection of fitness facility (mean values)

\begin{tabular}{|c|c|c|c|}
\hline Gym cleanliness & 3.53 & $\begin{array}{c}\text { Diversity of basic } \\
\text { services }\end{array}$ & 2.94 \\
\hline Gym equipment & 3.45 & $\begin{array}{l}\text { Choice of friends/ } \\
\text { acquaintances }\end{array}$ & 2.56 \\
\hline $\begin{array}{l}\text { Cleanliness of dressing } \\
\text { rooms and bathrooms }\end{array}$ & 3.41 & Parking opportunity & 2.34 \\
\hline Quality of basic services & 3.25 & $\begin{array}{c}\text { Quality of } \\
\text { supplementary services }\end{array}$ & 2.18 \\
\hline Coach & 3.18 & $\begin{array}{c}\text { Diversity of } \\
\text { supplementary services }\end{array}$ & 2.03 \\
\hline $\begin{array}{l}\text { Good atmosphere, } \\
\text { company }\end{array}$ & 3.11 & Workplace discount & 1.81 \\
\hline Price & 3.07 & $\begin{array}{l}\text { University physical } \\
\text { education classes }\end{array}$ & 1.64 \\
\hline Location in the city & 3.02 & & \\
\hline
\end{tabular}

Source: own edition. 
Table 5. Categories of factors influencing facility choice

\begin{tabular}{|c|c|c|}
\hline Factor & Statement & $\begin{array}{l}\text { Factor } \\
\text { loading }\end{array}$ \\
\hline \multirow{5}{*}{$\begin{array}{l}\text { Tangible } \\
\text { environment }\end{array}$} & Gym cleanliness & 0.83 \\
\hline & Gym equipment & 0.79 \\
\hline & $\begin{array}{l}\text { Cleanliness of dressing rooms } \\
\text { and bathrooms }\end{array}$ & 0.74 \\
\hline & Quality of basic services & 0.73 \\
\hline & Diversity of basic services & 0.62 \\
\hline \multirow[t]{2}{*}{$\begin{array}{l}\text { Supplementary } \\
\text { services }\end{array}$} & $\begin{array}{c}\text { Quality of supplementary } \\
\text { services }\end{array}$ & 0.9 \\
\hline & $\begin{array}{l}\text { Diversity of supplementary } \\
\text { services }\end{array}$ & 0.83 \\
\hline \multirow[t]{2}{*}{ Sociocultural factors } & $\begin{array}{l}\text { Choice of friends/ } \\
\text { acquaintances }\end{array}$ & 0.81 \\
\hline & Good atmosphere, company & 0.68 \\
\hline \multirow[t]{2}{*}{ Discounts } & Price & 0.78 \\
\hline & $\begin{array}{l}\text { University physical education } \\
\text { classes }\end{array}$ & 0.68 \\
\hline \multirow{2}{*}{$\begin{array}{l}\text { Factors related to } \\
\text { workplace }\end{array}$} & Location in the city & 0.83 \\
\hline & Workplace discount & 0.49 \\
\hline \multirow[t]{2}{*}{ Other factors } & Coach & 0.88 \\
\hline & Parking opportunity & 0.54 \\
\hline
\end{tabular}

Principal component analysis. Varimax with Kaiser Normalization. A. Rotation converged in 9 iterations. $\mathrm{KMO}=0.687$. Bartlett (Approx. Chi-Square) 3,332.981; $P<0.001$; communalities: 0.4860.842. Explained variance: $69,162 . N=753$.

Source: own edition.

We have studied how the consumers get clustered based on factors influencing their choices of facilities. As a result of the cluster analysis 5 homogenous consumer groups have been established that differ from each other at a significance level of $P<0.001$ as the variance analysis has demonstrated. Features of the clusters are summarised in Table 6.

The cluster whose members choose the venue for their training according to such characteristics of the gym that are linked to their workplace (location, discount) was named "Active worker". Those who chose facility on the basis of recreational facilities offered by extra services were classified into the "Active recreation" group. The "Sociable active" cluster includes sportsmen whose choice was highly influenced by socio-cultural factors and community-related aspects in addition to workplace-related attributes. Fitness consumers for whom price was the decisive factor in their fitness club choice were categorised into the "Active economical" cluster. The last cluster, which puts emphasis on all of the key features of the gym, on the tangible environment as well as on the services was named "Demanding consumers."

\subsection{Cluster 1: Active workers}

Two hundred twenty-three respondents have been included into this group. Their choices of fitness facilities are primarily influenced by workplace related factors, such as location of the fitness studio and workplace support and least influenced by additional services. As compared to the base population women $(79 \%)$ and older age groups are overrepresented. Their financial background and the frequency of visiting the fitness studios is similar to the average of the base population. As they participate in trainings regularly their choices are influenced by the location of the studio relative to their workplaces, therefore the name of the group is "Active workers".

The most populous of the groups consists of consumers, who expect fitness studios, as confirmed by the analysis of the results, to provide regular physical training so that they can preserve their health and shape their body to optimal appearance.

\subsection{Cluster 2: Active recreation fans}

The sample size of this cluster is 127. They find additional services the most important when deciding on the fitness studio. Price and good deals have the least influence on their choices. The older age groups are mostly represented in the cluster who are in a better financial situation compared to the base population, but are less active participants of fitness studios, they seldom go to fitness sessions. Additional services provide facilities for visitors of fitness studios where they can actively participate in recreation and leisure activities and therefore the group is named "Active recreation fans".

For them visiting the fitness studio is a leisure time activity at the same time, a program to spoil themselves, which they couple with sauna, massage or other beauty treatments.

\subsection{Cluster 3: Active in groups}

Eighty-nine respondents have been included in this group. Apart from the factors related to the workplace,

Table 6. Features of the clusters established based on the factors influencing consumers' choices

\begin{tabular}{|c|c|c|c|c|c|c|}
\hline Variable & $\begin{array}{c}\text { Active } \\
\text { workers } \\
N=223\end{array}$ & $\begin{array}{c}\text { Active recreation } \\
\text { fans } \\
N=127\end{array}$ & $\begin{array}{l}\text { Active in } \\
\text { groups } \\
N=89\end{array}$ & $\begin{array}{c}\text { Active } \\
\text { economical } \\
N=83\end{array}$ & $\begin{array}{c}\text { Demanding } \\
\text { consumers } \\
N=216\end{array}$ & Sig. \\
\hline Female & $79 \%$ & $65 \%$ & $61 \%$ & $66 \%$ & $56 \%$ & $P<0.001$ \\
\hline Male & $21 \%$ & $35 \%$ & $39 \%$ & $34 \%$ & $44 \%$ & \\
\hline Age & Older & Older & Average & Older & Younger & $P<0.001$ \\
\hline Financial status & Average & Better & Average & Average & Worse & 0.008 \\
\hline $\begin{array}{l}\text { Frequency of } \\
\text { training }\end{array}$ & Average & Rare & Frequent & Frequent & Rare & 0.003 \\
\hline
\end{tabular}

Source: Own edited. 
sociocultural aspects also play a crucial role in their choices while they disregard basic features of the fitness studios. As compared to the base population the rate of men in the group is higher (39\%) than the average of the base population (34\%). This is the most active cluster as they are the most frequent visitors of the studios, therefore they are called the "Active in groups".

As they spend a lot of time in the fitness salon, it is of particular interest for them to spend this time in good company, in a pleasant atmosphere. Fitness studios have little potential to shape companies. Buffets, spaces for chatting or the personality of the trainer may play a role in creating a welcoming atmosphere.

\subsection{Cluster 4: Active economical}

Eighty-three respondents are in this cluster. For them prices and good deals are the most important factors and less so workplace related ones. This is the oldest age group, and they attend fitness sessions more often than the base population. Based on the frequency of visiting fitness salons this group is characterised by an active lifestyle, nevertheless, the financial aspect of the trainings is also central for them and therefore we call this group "Active, economic".

Due to the frequency of trainings price is a more sensitive factor in their choices, particularly for the oldest age group. As they belong to the most motivated respondents it is worth supporting their activity with good deals.

\subsection{Cluster 5: Demanding consumers}

Altogether 216 people are in this group. For them the basic features (equipment and cleanliness) are the crucial factors. The least important for them are workplace related aspects. The rate of men (44\%) and the young is the highest here. They consider their financial situation to be a little below the average of the base population and they visit fitness clubs less frequently. They consider lots of factors when choosing a facility and therefore the name of the group is "Demanding consumers".

In choosing a fitness salon, first impressions, the appearance of the room, the features that are visible at first sight, like cleanliness and equipment play a decisive role, especially for young consumers. Cleanliness is a basic expectation here too, and that is why this group is most populous.

Based on the frequency of going to fitness sessions there is a significant difference among the five clusters with respect to gender, age and financial background at $P<0.001$, $P<0.001$, and $P<0.01$, respectively.

\subsection{Comparison of motivations of fitness consumers and factors influencing choice of facilities}

Finally, we analysed the relationship of clusters based on motivation versus clusters based on factors influencing choices of facilities with the help of correspondence testing, the results of which are depicted in Fig. 1.

It can be observed that there is a correspondence between certain motivations and factors influencing choices of facilities. It is not surprising that members of the Sociable, active cluster for whom sociocultural motivation is central, rely heavily on sociocultural factors when choosing a facility and share aspects with the Active in groups cluster. It must, however, be mentioned that in their choices of fitness facilities the motives of the Demanding visitors are also represented.

Members of the Active workers, who choose fitness venues based on workplace related factors (e.g., fair deals), are similar to the Externally controlled group in their main motivations, i.e., they start visiting fitness studios located close to their workplaces and are also influenced by other external expectations and appraisal.

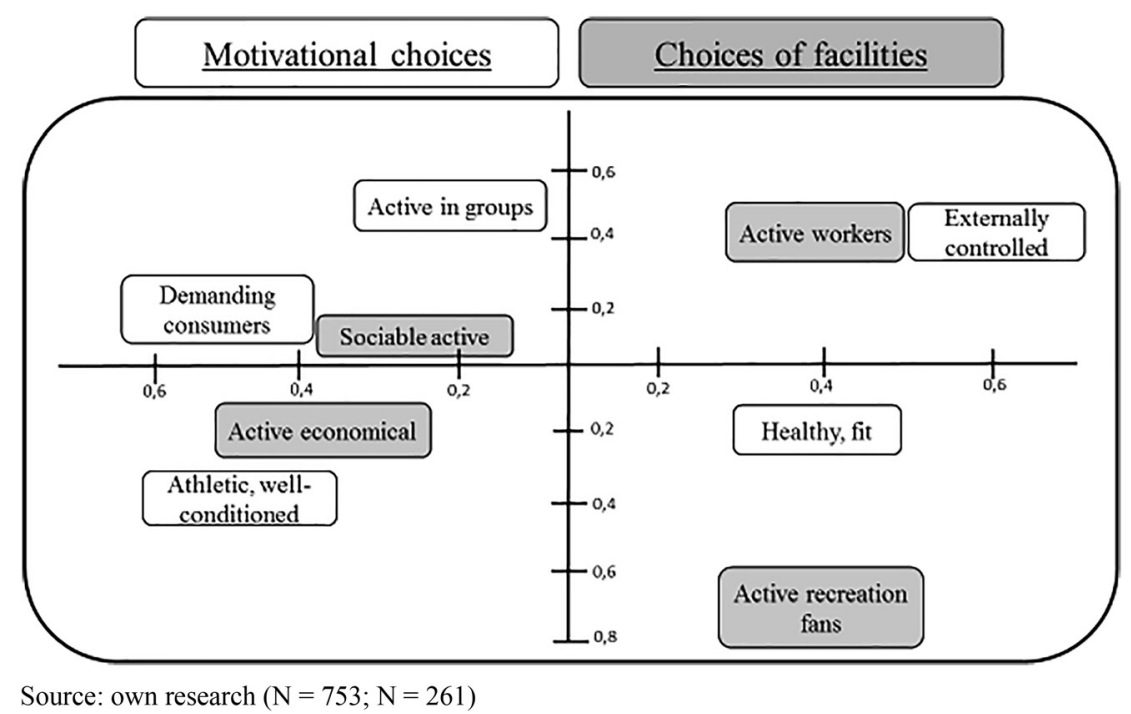

Fig. 1. Relationship of clusters based on motivation versus clusters based on factors influencing choices of facilities. Correspondence Analysis 
There is a correspondence between the Athletic, wellconditioned and Active economical clusters too, most likely established along financial aspects, since the members of the Athletic, well-conditioned cluster consider their financial status worse than the average of the base population, and consumers in the Active, economical cluster pay special attention to prices of services and deals.

Finally, mention must be made of dimensions that the Healthy, fit and Active recreational fans share. Members of the Healthy, fit cluster are older, just like of the Active recreational fans cluster. Both are characterised by intrinsic motivations. For them fitness sessions serve both physical and mental health and thus various leisure time activities offered as additional services that play a central role in their choice of facilities.

\section{CONCLUSIONS}

The results lead to the conclusion that similarly to the research of Kilpatrick et al. (2010) on exercises to achieve a well-conditioned body, the primary motivations of fitness consumers are linked to health and looks. It must, however, be pointed out that based on our research mental health related factors are of primary importance regarding participation in fitness sessions, as all three motivating factors in this group achieved an average of more than four. Compared to Frederick-Ryan's (1993) results, this means a difference as they considered body related motivations to be the central motivating factors for exercising. Life has accelerated since the 1990s; people are overwhelmed with information, they are to make quick decisions and they are forced to be in constant communication, which might well be in the background of our results. This lifestyle exhausts the mental side and thus the need to relieve stress is getting more emphasis. In line with this it has become generally known that physical activity as part of a health conscious behaviour contributes to mental health. Participating in regular physical activity has positive impact on many psychological disorders as anxiety, stress, depression and improves general psychological health [26-28].

The results of the study regarding choice of fitness facilities are partly in line with earlier studies, which claimed that the most important factors for fitness consumers were related to the physical environment [7, 9]. Prior research studies, however, do not handle physical environment, the issue of services and staff separately, they do not rank them in all cases. In our sample respondents found the material environment more important than the variety of programs, the staff and the price, which were also among the factors with a high value. However, in contrast to a previous research [29], customers in our sample were not price centric. According to Szabó (2012), facility choices of fitness consumers are largely influenced by the location of the facility within the town. The present research was not carried out in Budapest (the capital), but in Debrecen (the second largest town, a county seat), where shorter distances within the town could have little influence on respondents' assessment of the importance of the location. Moreover, the results support the claims of earlier studies stressing the significance of the staff; the trainer and the good atmosphere were two of the factors with high values in our sample. High values attributed to cleanliness and equipment prove the importance of first impressions from the point of view of consumers but at the same time they have to be kept up in order to maintain satisfaction in the long run.

We consider the segmentation of consumer groups a key outcome of our study. Based on the rank order of motivations influencing attendance of fitness sessions, fitness consumers were stratified into four different clusters. The "Sociable, active" cluster was made up of respondents who found sociocultural factors and appreciation to be the primary motivating factors. Members of the "Athletic, wellconditioned" group find developing the conditioning abilities and building muscles as their primary objective. Health conscious consumers, who do exercises to improve their health and achieve an attractive appearance are in the "Healthy, fit" cluster. And finally, athletes who visit fitness facilities because they are bound by duty, or want to meet expectations or want appreciation from external sources were categorised into the "Externally controlled" cluster.

Then, segmentation of the consumers was done based on the factors influencing their choices of facilities. As a result of our cluster analysis 5 consumer groups were established. The cluster "Active workers" comprises people who choose fitness studios on the basis of workplace related factors (location, deals). Respondents who make their choices based on recreational possibilities offered as additional services were classified as "Active recreation fans". "Active in groups" is the cluster the members of which found workplace related factors of essential importance but attributed high value to sociocultural factors and the community. Fitness consumers for whom price plays a decisive role when choosing a facility were included into the "Active economical" cluster. Finally, the cluster "Demanding visitors" was created consisting of respondents for whom all important features of the fitness studio, the material environment and the services were of high importance. Consequently, the results demonstrate that fitness studio consumers can be clustered into different, well-defined groups both on the basis of their primary motivations and the factors influencing their choice of fitness facilities.

In our research we presumed that taking motivations and facility choices of customers into consideration, as well as ensuring appropriate personnel will sustain society's physical activity level and with it its health condition in the long run. We managed to identify the most active and less active groups of fitness consumers.

We have stated that for groups of older recreational athletes preservation of their health and the intention to spend time in pleasant company are important motivational factors. We categorised the young into groups of different activity levels for whom improving their looks is considered to be a critical motivating factor, just like external pressure, which might come from parents or other reference groups. 
Our results lead to the conclusion that the motivation of consumer groups identified in our research can be sustained in the long run, the less active groups can be better involved and attracted to sports offered by fitness centres, on condition the fitness studios reliably serve these needs and provide the expected variety of services and hygienic conditions.

The aim of our research was to examine fitness consumers. Few studies have been conducted in Hungary in this field, so the present research is primarily exploratory. Due to the material and time constraints, our sample is not representative. Our study was concentrated on the motivations and facility choices of fitness consumers in Hungary. However, subsequent studies could also examine the expectations and perceptions of fitness service quality and could help in studying other sport-related facilities too.

Understanding customers' motivations and expectations are proved to be essential parameters for fitness facility managers [30].

\section{ACKNOWLEDGEMENTS}

The publication is supported by the EFOP-3.6.1-16-201600022 project. The project is co-financed by the European Union under the European Social Fund.

\section{REFERENCES}

[1] J. León-Quismondo, J. García-Unanue, and P. Burillo, "Best practices for fitness center business sustainability: a qualitative vision," Sustainability, vol. 12, p. 5067, 2020. https://doi.org/10. 3390/su12125067.

[2] K. W. Lambrecht, "An analysis of the competencies of sports and athletic club managers," J. Sport Manage., vol. 1, pp. 116-28, 1987.

[3] A. Tripolitsioti, "Impact of demographic factors on management competencies of the municipal sport organizations," CHOREGIA, vol. 12, 2016. https://doi.org/10.4127/ch.2016.0106.

[4] L. Robinson, "Following the quality strategy: the reasons for the use of quality management in the UK public leisure services," in Proceedings of the 6th Congress of the European Association for Sport Management, Madeira, 1998.

[5] P. A Chelladurai, "Classification of sport and physical activity services: implications for sport management," Hum. Kinet. J., vol. 6, no. 1, pp. 38-51, 1992.

[6] N. Maksimovic, R. Matic, S. Tovilovic, S. Popovic, B. Maksimović, and S. Opsenica, "Quality of services in fitness centres: importance of physical support and assisting staff," S. Afr. J. Res. Sport Phys. Educ. Recreat., vol. 39, pp. 67-78, 2017.

[7] Y. Afthinos, N. Theodorakis, and P. Nassis, "Customers expectations of service in Greek fitness centers. Gender, age, type of sport center and motivation differences," Manag. Serv. Qual., vol. 15, no. 3, pp. 245-58, 2005.

[8] P. Chelladurai, and K. Chang, "System-based quality dimensions in fitness services: development of the scale of quality," Serv. Ind. J., vol. 23, no. 5, pp. 65-83, 2003.
[9] D. Kim, and S. Y. Kim, "QUESC: an instrument for assessing the service quality of sport centers in Korea," J. Sport Manage., vol. 9, no. 2, pp. 208-22, 1995.

[10] P. Chelladurai, and K. Chang, "Targets and standards of quality in sport services," Sport Manage. Rev., vol. 3, no. 1, pp. 1-22, 2000.

[11] Á. Szabó, "A magyar szabadidősport müködésének vizsgálata. Piacok, értékteremtés, feladatok a szabadidősportban,” Ph.D. thesis, Budapest, 2012.

[12] M. Kilpatrick, E. Hebert, and J. Bartholomew, "College students' motivation for physical activity: differentiating men's and women's motives for sport participation and exercise," J. Am. Coll. Health, vol. 54, no. 2, pp. 87-94, 2010.

[13] K. Molanorouzi, S. Khoo, and T. Morris, "Motives for adult participation in physical activity: type of activity, age, and gender," BMC Publ. Health, vol. 15, no. 66, 2015.

[14] K. Geller, K. Renneke, S. Custer, and G. Tigue, "Intrinsic and extrinsic motives support adults' regular physical activity maintenance," Sports Med. Int. Open, vol. 2, no. 3, pp. E62-6, 2018, Published 2018 Jun 17 https://doi.org/10.1055/a-0620-9137.

[15] A. Gál, Innovativ es kreatív kommunikációs, média- és marketing tartalmak az egészségfejlesztést szolgáló fizikai aktivitás fokozásának szolgálatában. Budapest: TÁMOP tanulmány, 2014.

[16] S. J. H. Biddle, and N. Mutrie, Psychology of Physical Activity: Determinants, Well-Being and Interventions. London: Routledge, 2011.

[17] C. M. Frederick, and R. M. Ryan, "Differences in motivation for sport and exercise and their relations with participation and mental health," J. Sport Behav., vol. 16, no. 3, pp. 124-46, 1993.

[18] Á. Neulinger, Társas környezet és sportfogyasztás - A folyamatos megerösitést igénylö tanult fogyasztás Ph.D. thesis, Budapesti Corvinus Egyetem, Budapest, 2007.

[19] B. Bauer, P. Pillók, T. Ruff, A. Szabó, F. E. Szanyi, and L. Székely, "Magyar Ifjúság Kutatás". http://www.ujnemzedek.hu/sites/default/ files/magyar_ifjusag_2016_a4_web.pdf Accessed: Aug. 22, 2018.

[20] Á. Neulinger, "A szabadidősport iránti érdeklődés - motivációk," Magyar Sporttudományi Szemle, vol. 10, no. 37, pp. 25-8, 2009.

[21] D. Kehl, and G. Rappai, "Mintaelemszám tervezése Likert-skálát alkalmazó lekérdezésekben,” Statisztikai Szemle, vol. 84, no. 9, pp. 848-75, 2006.

[22] G. Fábián, Alkalmazott kutatás módszertan, 2014, TÁMOP-4.1.2 A1 és TÁMOP 4.1.2 A2 könyvei.

[23] L. Sajtos, and A. Mitev, SPSS kutatási és adatelemzési kézikönyv. Budapest: Alinea Kiadó, 2007.

[24] É. Bartha, and É. Bácsné Bába, "Fogyasztói motivációs vizsgálatok fitnesz szolgáltatást igénybe vevők körében," Int. J. Eng. Manag. Sci., vol. 3, no. 4, pp. 442-53, 2018.

[25] É. Bartha, and É. Bácsné Bába, "A sportlétesítményválasztást befolyásoló legfóbb szempontok vizsgálata a fitnesz szolgáltatást igénybe vevő férfiak és nők körében," TAYLOR Gazdálkodás- és szervezéstudományi folyóirat, vol. 11, pp. 5-14, 2019. https://ojs. bibl.uszeged.hu/index.php/taylor/article/view/21996.

[26] A. M. Al-Qahtani, M. A. K. Shaikh, and I. A. Shaikh, "Exercise as a treatment modality for depression: a narrative review," Alexandria J. Med., vol. 54, no. 4, pp. 429-35, 2018. https://doi.org/10.1016/j. ajme.2018.05.004.

[27] M. C. Pascoe, and A. G. Parker, "Physical activity and exercise as universal depression prevention in young people: a narrative review," Early Interv. Psychiatr., vol. 13, no. 4, pp. 733-9, 2019. https://doi.org/10.1111/eip.12737. 
[28] T. Muhsen, and M. Muhsen, "The impact of physical activity and sport on mental health," Journal of Physical Education, vol. 32, no. 3, pp. 160-5, 2020. Available: https://jcope.uobaghdad.edu.iq/ index.php/jcope/article/view/1032.

[29] Y. Khisti, and S. Raizada, "A study on consumer behaviour to joining gym in Ahmednagar," Ann. Trop. Med. Publ. Health, vol.
23, no. S17, p. SP231757, 2020. http://doi.org/10.36295/ASRO. 2020.231757.

[30] P. Eirini, S. Chatzi, and D. Kissa, "Service quality expectations in the fitness center context: a validation of the expectations component of the SERVQUAL scale in Greece," Serv. Market. Q., 2020. http://doi.org/10.1080/15332969.2020.1742977.

Open Access. This is an open-access article distributed under the terms of the Creative Commons Attribution 4.0 International License (https://creativecommons.org/ licenses/by/4.0/), which permits unrestricted use, distribution, and reproduction in any medium, provided the original author and source are credited, a link to the CC License is provided, and changes - if any - are indicated. (SID_1) 